University of Nebraska - Lincoln

DigitalCommons@University of Nebraska - Lincoln

Searching for synergism in dryland cropping systems in the central Great Plains

David C. Nielsen

USDA-ARS, Central Great Plains Research Station, dcnielsen55@gmail.com

Merle F. Vigil

USDA-ARS, Central Great Plains Research Station

Follow this and additional works at: https://digitalcommons.unl.edu/usdaarsfacpub

Nielsen, David C. and Vigil, Merle F., "Searching for synergism in dryland cropping systems in the central Great Plains" (2014). Publications from USDA-ARS / UNL Faculty. 1472.

https://digitalcommons.unl.edu/usdaarsfacpub/1472

This Article is brought to you for free and open access by the U.S. Department of Agriculture: Agricultural Research Service, Lincoln, Nebraska at DigitalCommons@University of Nebraska - Lincoln. It has been accepted for inclusion in Publications from USDA-ARS / UNL Faculty by an authorized administrator of DigitalCommons@University of Nebraska - Lincoln. 


\title{
Searching for synergism in dryland cropping systems in the central Great Plains
}

\author{
David C. Nielsen*, Merle F. Vigil \\ USDA-ARS, Central Great Plains Research Station, 40335 County Road GG, Akron, 80720, CO, United States
}

\section{A R T I C L E I N F O}

\section{Article history:}

Received 13 September 2013

Received in revised form

18 December 2013

Accepted 22 December 2013

\section{Keywords:}

Wheat

Corn

Millet

Pea

Dryland cropping systems

Rotations

Water use

Yield

Water use efficiency

Synergism

\begin{abstract}
A B S T R A C T
Previously published research reported a "synergistic effect" of corn (Zea mays L.) on winter wheat (Triticum aestivum L.) and proso millet (Panicum miliaceum L.) water use efficiency (WUE) when corn (C) was the preceding crop for dryland cropping systems in the central Great Plains, i.e., less water was required to grow a unit of wheat $(\mathrm{W})$ or proso millet $(\mathrm{M})$ when corn was the preceding crop. A similar synergistic effect of field pea (Pisum sativum $\mathrm{L}$.) for seed (P) or forage ( $\mathrm{FrP}$ ) on winter wheat water use and yield has also been reported. The purpose of this study was to examine a long-term cropping systems yield and water use data set in order to determine if WUE is altered by rotational sequence (i.e., previous crop). Yield and water use data (computed by water balance using neutron probe and time-domain reflectometry measurements) were acquired from a crop rotation study conducted at Akron, $\mathrm{CO}$ from 1996 to 2011 using the following rotation sequences: W-fallow (F), W-C-F, W-M-F, W-C-M, W-M, W-W-C-M,W-C-M-F, W-C-M-P, W-C-M-FrP and W-M-Sunflower (S, Helianthus annuus L.)-F. Water use efficiency was computed as grain yield divided by water use. Changes in WUE due to crop rotation were also evaluated based on slopes of water use/yield production functions. The analysis of these data did not support a conclusion that corn has a synergistic effect of improving WUE of wheat or millet production nor the conclusion that pea has a synergistic effect on wheat.
\end{abstract}

Published by Elsevier B.V.
Mention of trade names or commercial products in this publication is solely for the purpose of providing specific information and does not imply recommendation or endorsement by the U.S. Department of Agriculture.

The U.S. Department of Agriculture (USDA) prohibits discrimination in all its programs and activities on the basis of race, color, national origin, age, disability, and where applicable, sex, marital status, familial status, parental status, religion, sexual orientation, genetic information, political beliefs, reprisal, or because all or part of an individual's income is derived from any public assistance program. (Not all prohibited bases apply to all programs.) Persons with disabilities who require alternative means for communication of program information (Braille, large print, audiotape, etc.) should contact USDA's TARGET Center at (202) 720-2600 (voice and TDD) To file a complaint of discrimination, write to USDA, Director, Office of Civil Rights, 1400 Independence Avenue, S.W., Washington, D.C. 20250-9410, or call (800) 795-3272 (voice) or (202) 720-6382 (TDD). USDA is an equal opportunity provider and employer.

\footnotetext{
* Corresponding author.

E-mail addresses: david.nielsen@ars.usda.gov, dcnielsen55@gmail.com (D.C. Nielsen).
}

\section{Introduction}

Anderson (2005a) asked the question, "Are some crops synergistic to following crops?" and presented data indicating that the answer to that questions was "Yes." In that paper synergism was defined as improved crop WUE in response to a specific preceding crop in a rotational sequence. He concluded that corn in a crop rotation improved the WUE of the subsequent winter wheat crop, i.e., wheat yielded greater for the same water use when corn was in the rotation compared with when proso millet was in the rotation. The mechanism for this improved WUE was not identified. A similar conclusion was stated in Anderson (2004) regarding corn improving proso millet yield, and dry pea grown as a forage improving winter wheat WUE compared with winter wheat or proso millet as the previous crop.

Kirkegaard et al. (2008) provided an extensive literature review of previous crop effects on wheat yield from studies done in North America, southern Australia, and northern Europe. These systems were identified as "break crop" systems and generally showed increased wheat yield compared with continuous wheat yield. However, data regarding changes in WUE were not presented. The yield increases were attributed to fewer diseases, greater residual fertility $(N$ and $P$ ), and greater available soil water at planting following the break crop than following a previous wheat crop. The reviewed studies that were conducted in the semi-arid regions of 
North America, particularly the northern Great Plains of the United States, did not consistently show the positive yield benefits of the break crop, most likely because of the overriding influence of available soil water on wheat yield combined with the highly variable nature of precipitation amount and timing in this region.

In a 4-year study conducted in eastern Montana, USA, Lenssen et al. (2007) reported spring wheat grain WUE ranging widely from 0.3 to $12.3 \mathrm{~kg} \mathrm{ha}^{-1} \mathrm{~mm}^{-1}$. The wide range in values was attributed to water availability effects on yield. They did not report consistent effects of previous crop type on WUE of spring wheat, but WUE was generally lower when wheat was preceded by a crop than when wheat was preceded by a fallow period. Lyon et al. (2007) reported results from a 2-year study conducted at two central Great Plains locations (Nebraska Panhandle, northeastern Colorado) in which the effects of preceding crop (triticale [ $X$ Triticosecale Wittmack], pea, foxtail millet [Setaria italica L. Beauv.], proso millet) and starting soil water content on subsequent winter wheat yield and water use were determined. Their data also showed that WUE varied widely over the course of the study ( 1.45 to $8.71 \mathrm{~kg} \mathrm{ha}^{-1} \mathrm{~mm}^{-1}$ ) and that greater WUE was observed when soil water contents at wheat planting were high. Those initial soil water contents were more influenced by precipitation amounts prior to wheat planting than by specific crop preceding winter wheat. In particular they did not report greater WUE for wheat following pea than for wheat following triticale, foxtail millet, or proso millet.

Results from a rotation study conducted in Swift Current, SK, Canada (Miller et al., 2003) indicated that 3-year average spring wheat WUE was improved when wheat followed a broadleaf crop (pea, lentil, chickpea, mustard) compared with wheat following wheat grown on a clay soil, but this difference was not seen when grown on a silt loam soil. The significant WUE improvement noted on the clay soil was attributed mainly to low yields for the wheatfollowing-wheat system which may have suffered from increased soil-borne pathogens during above-average precipitation years.

Tanaka et al. (2005) reported yield data from a cropping matrix study conducted at Mandan, ND in which previous crop effects on subsequent crop yields were analyzed over a 2-year period for 10 crop species. Some statistically significant yield differences due to previous crop species were presented, but the results were not consistent between the two years. For example, in one year spring wheat yield was unaffected by previous crop species, while in the second year spring wheat yields were significantly greater when the previous crop was crambe (Crambe abyssinica $\mathrm{H}$.), dry bean (Phaseolus vulgaris L.), pea, or safflower (Carthamus tinctorius L.), but not with any of the other six plant species grown ahead of the wheat crop. Unfortunately no soil water or WUE data were provided so it is impossible to determine if these four species had the synergistic effect on wheat yield that Anderson (2005a) defined as improved WUE.

Hatfield et al. (2001) reviewed literature regarding soil management effects on WUE. They stated that increasing soil water availability to the crop in the absence of any other yield-limiting factors can lead to increased WUE. This can occur as a result of employing no-till management that leads to lower evaporative losses of soil water, increased precipitation infiltration on some soil types, and greater snow catch in standing crop residues. It is possible that different preceding crops will produce different amounts and orientations of crop residues that could lead to differences in soil water content at wheat planting. These differences in soil water content at wheat or millet planting could lead to plants under differing water stress during critical flowering and grain filling stages that could result in WUE differences in differing rotational sequences. Additionally there may be differing amounts of previous crop residue on the soil surface during the wheat or millet growing seasons which could lead to differing ratios of evaporation to transpiration resulting in WUE differences.
Hatfield et al. (2001) noted the difficulty in interpreting results from WUE studies because of the variation among seasons. These seasonal variations are, in semi-arid climates, mostly a result of the effects of the widely varying timing, amount, and form of precipitation (rain/snow) on both the previous crop and the current crop. Nielsen and Halvorson (1991) reported 30\% greater WUE for non-N-stressed winter wheat in a year with $39 \%$ of growing season precipitation occurring during heading and flowering compared with a year with only $8 \%$ of growing season precipitation occurring during that critical developmental period (10.39 and $7.99 \mathrm{~kg} \mathrm{ha}^{-1} \mathrm{~mm}^{-1}$, respectively). Consequently short-term studies may lead to erroneous conclusions regarding crop effects on subsequent crop WUE.

In the absence of sufficiently long-term studies that could adequately identify synergistic effects of cropping practices to improve WUE, cropping systems simulation models may be used. Kirkegaard and Hunt (2010) used the Agricultural Production Systems Simulator (APSIM, Keating et al., 2003) to simulate multiple management effects (minimum tillage, weed control, crop rotation, planting date, and genotype selection) on wheat yield and WUE in southeastern Australia. They found combinations of management practices simulated over a 48-year period increased yields more than implementing any single practice, and that WUE increased from $6.0 \mathrm{~kg} \mathrm{ha}^{-1} \mathrm{~mm}^{-1}$ for a baseline conventional till W-F system to $15.2 \mathrm{~kg} \mathrm{ha}^{-1} \mathrm{~mm}^{-1}$ for a system in which all five of the suggested management practices were employed. Saseendran et al. (2010) simulated several central Great Plains dryland cropping systems and reported 16-year average wheat yields that were the same for the $\mathrm{W}-\mathrm{F}$ and $\mathrm{W}-\mathrm{C}-\mathrm{F}$ no-till systems. The simulated average wheat yield for the $\mathrm{W}-\mathrm{M}-\mathrm{F}$ rotation was numerically greater than for $\mathrm{W}-\mathrm{F}$ or W-C-F, but not significantly so. The simulated WUE values were $3.13,4.51$, and $3.89 \mathrm{~kg} \mathrm{ha}^{-1} \mathrm{~mm}^{-1}$ for $\mathrm{W}-\mathrm{F}, \mathrm{W}-\mathrm{C}-\mathrm{F}$, and $\mathrm{W}-\mathrm{M}-\mathrm{F}$, respectively.

Winter wheat yields from an alternative crop rotation (ACR) study at Akron, CO (Anderson et al., 1999) were averaged over the 1994 to 1999 time period and found to be $8 \%$ greater (nonsignificant) in a wheat-corn-fallow system than in a wheat-fallow system, but yields in a wheat-proso millet-fallow system were the same as in the wheat-fallow system. Anderson (2005a) also concluded that dry pea improved WUE of winter wheat compared with winter wheat, proso millet, or fallow preceding winter wheat based on data from Anderson (2002). Tanaka et al. (2005) stated that WUE of winter wheat increased $56 \%$ when following dry pea (W-C-P rotation) compared with following proso millet (W-C-M rotation). Data presented in Anderson $(2010,2011)$ indicated that the 2-year average winter wheat WUE was $12 \%$ greater following pea compared with following fallow (comparing data from the W-C-M-P and $\mathrm{W}-\mathrm{C}-\mathrm{M}-\mathrm{F}$ rotations at Akron, $\mathrm{CO}$ ).

The objective of this paper was to re-examine some of the data presented in the literature cited above from Akron and compare it with a larger data set from the ACR study at Akron and determine if the conclusion regarding crop synergism (enhanced WUE due to specific previous crop) is consistently observed.

\section{Materials and methods}

The data presented in this paper come from the long-term ACR study conducted at the USDA-ARS Central Great Plains Research Station, $6.4 \mathrm{~km}$ east of Akron, $\mathrm{CO}\left(40^{\circ} 09^{\prime} \mathrm{N}, 103^{\circ} 09^{\prime} \mathrm{W}\right.$, 1384 ma.s.l). The soil type was a Weld silt loam (fine, smectitic, mesic Aridic Argiustoll). The experiment was established in the fall of 1990 to compare tillage, rotational sequence, and cropping intensity/frequency effects on soil properties, precipitation storage efficiency, crop water use, and crop production under the dryland, semiarid conditions of this region of the central Great Plains. More 
than 20 rotational sequences were established with winter wheat, corn, proso millet, field pea, grain sorghum (Sorghum bicolor L. Moench), winter triticale, sunflower, safflower, and foxtail millet. Cropping intensity varied from one crop in two years (W-F) to two crops in three years (e.g., W-C-F) to three crops in four years (e.g., $\mathrm{W}-\mathrm{C}-\mathrm{M}-\mathrm{F}$ ) to continuous cropping. Rotations were treatments in a randomized complete block design with three replications. All phases of each rotation were present every year. Individual plot size was $9.1 \mathrm{~m}$ by $30.5 \mathrm{~m}$. Nitrogen fertilizer rates varied from year to year based on typical application rates for dryland production in the area and periodic soil testing. Seed yield sample size was generally between 35 and $42 \mathrm{~m}^{2}$.

Soil water was measured to a depth of $1.65 \mathrm{~m}$ in $0.30 \mathrm{~m}$ intervals using a neutron probe (Model 503 Hydroprobe, CPN International, Martinez, CA) for all depths except the 0.0 to $0.3 \mathrm{~m}$ layer. Soil water in this surface layer was determined using time-domain reflectometry (Trase System I, Soil Moisture Equipment Corp., Santa Barbara, CA) with $0.3 \mathrm{~m}$ waveguides installed vertically to average the water content over the entire layer. The neutron probe was calibrated against gravimetric soil water samples taken in the plot area. Gravimetric soil water was converted to volumetric water by multiplying by the soil bulk density for each depth. Bulk density was determined from the dry weight of the soil cores $(38 \mathrm{~mm}$ diameter by $300 \mathrm{~mm}$ length) taken from each depth at the time of neutron probe access tube installation. Two measurement sites were located near the center of each plot and data from the two sites were averaged to give one reading of soil water content for each plot.

Full season water use was calculated from the water balance as the difference between soil water readings at planting and physiological maturity plus growing season precipitation (runoff and deep percolation were assumed to be negligible, considered a reasonable assumption as the slope in the plot area was $<1 \%$ and visual observation in the plot area following heavy rains did not show evidence of runoff). Additionally spring season water use was calculated for wheat for the time period from spring green-up (about 15 March) to physiological maturity. Water use efficiency was calculated as the seed yield divided by the water use from either the full season or the spring season period. Anderson (2005a) had reported WUE based on spring season water use, but we believe that full season water use rather than spring season water use should be reported as the more applicable term for evaluating differences in water use and WUE due to crop sequence as it is important to account for all of the water use by the crop.

The interactions of precipitation timing and amount, crop residue mass and orientation, length and season of fallow period, and particular crop sequence greatly influence precipitation storage efficiency, water content at planting, and crop water use (Nielsen and Vigil, 2010; Benjamin et al., 2010; Nielsen et al., 2002; Farahani et al., 1998). Soil water content at planting has a strong influence on crop yield (Nielsen et al., 1999; Nielsen and Vigil, 2005; Felter et al., 2006, Lyon et al., 2007; Nielsen et al., 2008). Therefore, data from the first five years of the study (1991-1995) are not considered in the analysis presented in the paper (1996-2011) as we considered those years to be the time period in which the rotations were being established and from which time forward the true effects of the rotational sequences, primarily due to differences in soil water content, could be evaluated.

The data were analyzed as a split plot design with year as the main plot and crop rotation/previous crop as the split plot using Statistix 9 software (Analytical Software, Tallahassee, FL). Statistically significant differences in yield, available soil water at planting, water use, and WUE due to rotation/previous crop were determined using the Tukey's $\mathrm{HSD}_{0.05}$ mean separation test when more than two rotations were compared and using the F statistic for the rotation effect from the split plot analysis when only two rotations were compared.
In addition to analyzing the data for differences in WUE due to crop rotation, we used the Statistix 9 software to compute linear regressions of yield on water use and compared the regression slopes and intercepts for differences due to rotation using the regression line comparison feature of the Statistix 9 software. This analysis allowed us to search for synergism in a somewhat different form of WUE, namely changes in the slope of the water use/yield production function. Analysis of WUE in this manner avoids the inclusion of the crop water use which may not be associated with grain yield formation (the intercept of the regression relationship) and may be more sensitive to differences due to crop rotation. The Statistix 9 software was also used to perform best subset regression analysis of several environmental parameters on WUE in an attempt to determine which factors were most influential to WUE.

\section{Results}

\subsection{Synergistic effect of corn on winter wheat}

Fig. 1a presents winter wheat yield and spring season water use (spring green up to maturity) data for the $\mathrm{W}-\mathrm{C}-\mathrm{F}$ reduced-till, W-C-F no-till and W-M-F no-till rotations, averaged over the three replicate plots for each rotation for years 1996, 1997, and 1998. Anderson (2005a) based his conclusions on the comparison of the $\mathrm{W}-\mathrm{C}-\mathrm{F}$ reduced till data with the W-M-F no-till data. Error bars indicate one standard deviation about the mean yield and spring season water use values. These data seem to show that there was greater yield for a similar water use in the $\mathrm{W}-\mathrm{C}-\mathrm{F}$ reduced-till rotation than in the $\mathrm{W}-\mathrm{M}-\mathrm{F}$ rotation, but probably not in the $\mathrm{W}-\mathrm{C}-\mathrm{F}$ no-till rotation. Results and conclusions are similar for Fig. 1b, which shows the relationship between yield and full season water use (from planting to maturity).

The data points in Fig. 1a and 1b separate into groups by year in which the data were collected as noted by the circles in the figures. The exception is the 1996 point for WCF reduced till, for which we do not have an explanation for the much lower water use than seen with the other two rotations in 1996. Greatest yields and water use were measured in 1996 when the sum of available soil water at planting $(0-180 \mathrm{~cm}$ soil profile) plus growing season precipitation was $533 \mathrm{~mm}$. The lowest yields and water use were measured in 1998 when the sum of soil water and precipitation was $306 \mathrm{~mm}$. In 1997 the sum of soil water and precipitation was $380 \mathrm{~mm}$, resulting in intermediate water use but similar yields to 1996 . The similar high yields in 1997 compared with 1996 but with lower water use are probably a result of both slightly cooler growing season temperatures in 1997 compared with 1996 and of more favorable timing of precipitation with 29\% of total growing season precipitation falling in June in 1997 compared with 24\% falling in June 1996 (flowering and grain filling stages).

Fig. 1c and d show the relationship between yield and the two water use quantities for a longer period (16 years, 1996 to 2011). The $\mathrm{W}-\mathrm{C}-\mathrm{F}$ reduced-till rotation was changed to a different rotation in 1999, so further comparisons between this rotation and W-M-F were not possible. Linear regression lines with $95 \%$ confidence intervals were fit to the data points in these two panels. The comparisons of regression slopes and intercepts ( $p$ values shown in figure) indicate that the relationship between wheat yield and water use is not different when corn is in the rotation compared with when millet is in the rotation. The relationship between average (1997-2011) full season water use and yield for wheat is nearly identical for rotations with and without corn (Fig. 2), and supports the conclusion that wheat WUE is not improved when corn appears as a rotational phase. The relationships are defined as: $\mathrm{kg} \mathrm{ha}^{-1}=10.20(\mathrm{~mm}-113)\left[R^{2}=0.98, n=4\right]$ for rotations without 

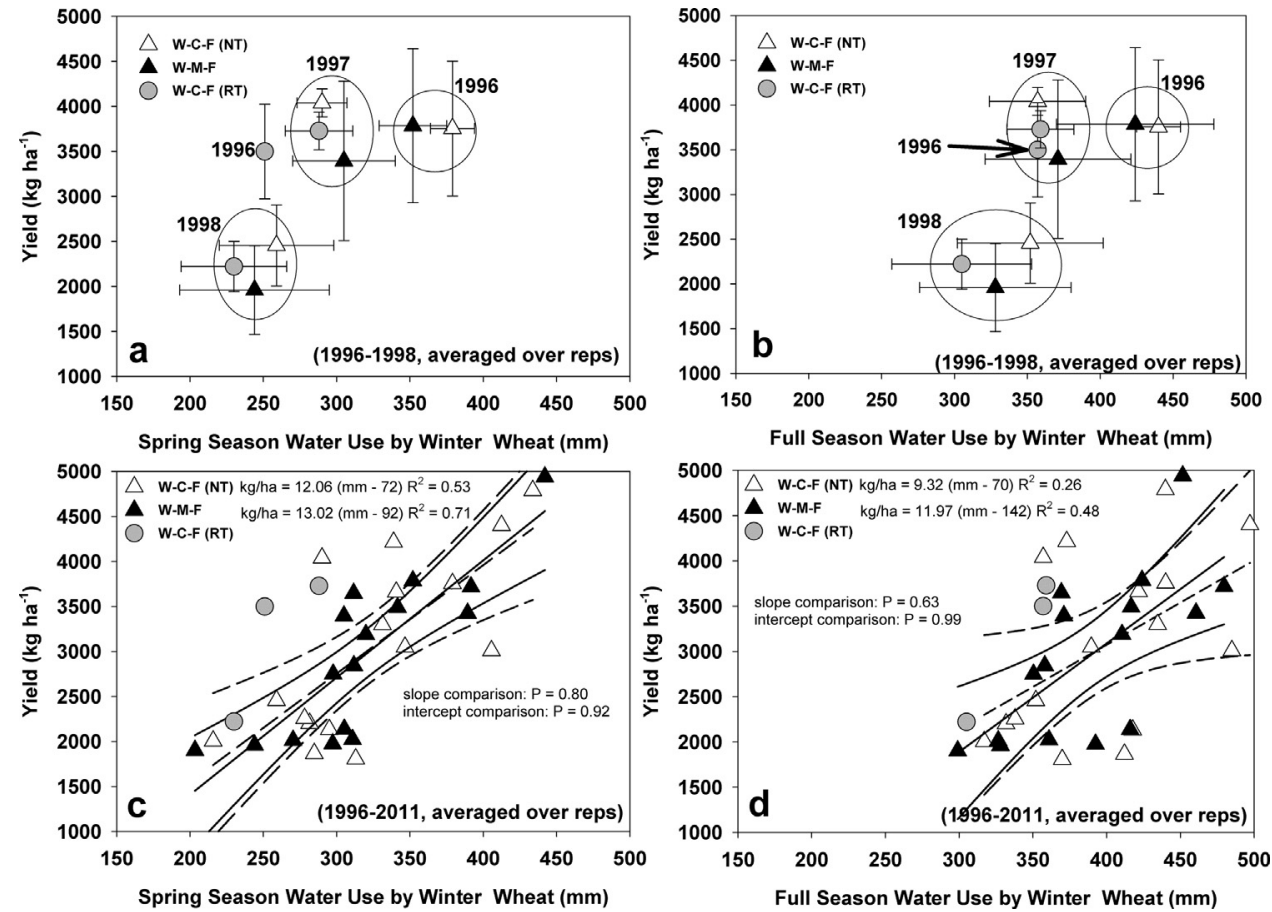

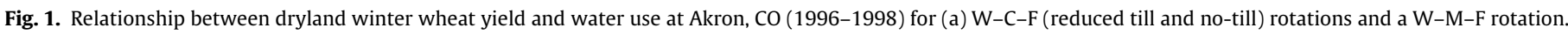

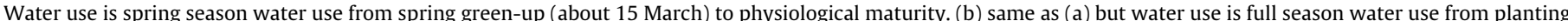

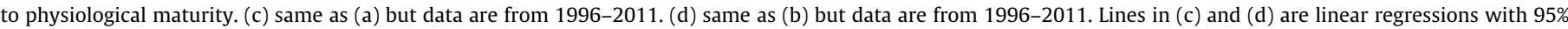

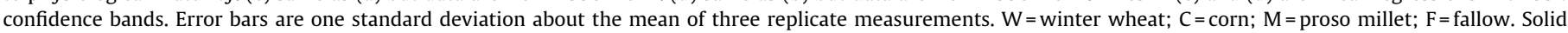
regression lines and 95\% confidence intervals are for $\mathrm{W}-\mathrm{M}-\mathrm{F}$ and dashed regression lines and 95\% confidence intervals are for $\mathrm{W}-\mathrm{C}-\mathrm{F}$ (no-till).

corn, and $\mathrm{kg} \mathrm{ha}^{-1}=11.54(\mathrm{~mm}-140)\left[R^{2}=0.98, n=6\right]$ for rotations with corn.

Slopes and intercepts were not significantly different due to corn being present in the rotations ( $p=0.37$ for slope comparison and 0.93 for intercept comparison). Regardless of whether corn is present in a rotation or not, wheat yield responds to full season water use at the rate of about $11 \mathrm{~kg} \mathrm{ha}^{-1} \mathrm{~mm}^{-1}(n=10)$. Data are averaged over the period 1997-2011 rather than 1996-2011 because data were not available for $\mathrm{W}-\mathrm{C}-\mathrm{M}-\mathrm{FrP}, \mathrm{W}-\mathrm{W}-\mathrm{C}-\mathrm{M}$, $\mathrm{W}-\mathrm{M}$, and $\mathrm{W}-\mathrm{C}-\mathrm{M}$ rotations in 1996 . Each data point is the average of 45 individual data points [15 years, 3 replications per year]). The plot of yield vs. spring season water use (data not shown) looks nearly identical to Fig. 2, with a regression slope of

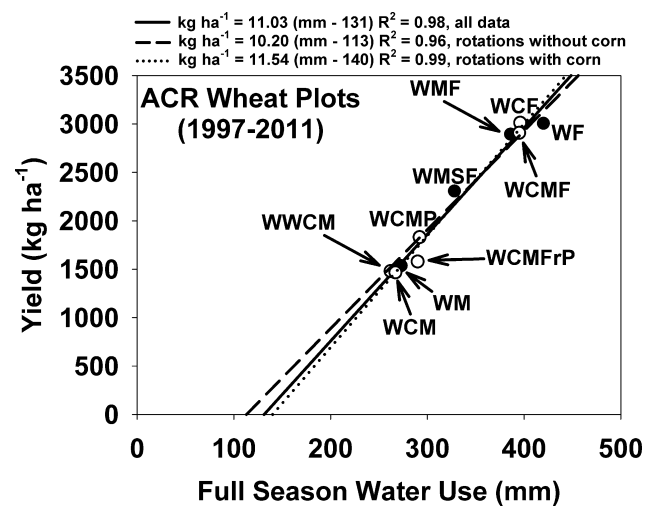

Fig. 2. Relationship between average (1997-2011) winter wheat yields and full season water use (planting to physiological maturity) for 10 dryland cropping systems at Akron, CO. Open circles are cropping systems with corn as a constituent phase; filled circles are cropping systems without corn as a constituent phase. $(\mathrm{W}=$ winter wheat; $C=$ corn; $M=$ proso millet; $P=$ field pea; $F r P=$ forage pea; $S=$ sunflower or safflower; $F=$ fallow). Each data point is the average of 15 individual data points (15 years, 3 replications per year).
$14.3 \mathrm{~kg} \mathrm{ha}^{-1} \mathrm{~mm}^{-1}$, a water use offset of $117 \mathrm{~mm}$, and $R^{2}=0.97$. The 15-year average wheat yield (Fig. 3) from WCF was not different from the average yield for WMF or WF (all no till systems).

\subsection{Synergistic effect of corn on proso millet}

The table given in Anderson (2005a) of 4-year average (1996-1999) proso millet grain yield, available soil water at planting, water use, and WUE is reproduced for reference in Table 1, section labeled "Anderson (2002, 2005a, 2005b)". These data indicated that there was a $24 \%$ increase in millet WUE (due to $15 \%$ greater yield with similar water use) when corn was the preceding crop in the rotation ( $\mathrm{W}-\mathrm{C}-\mathrm{M})$ compared with wheat as the preceding crop (W-M). We have taken data for those four years (1996-1999) from our archive and present those data in Table 1, section labeled "Akron alternative crop rotation data archive

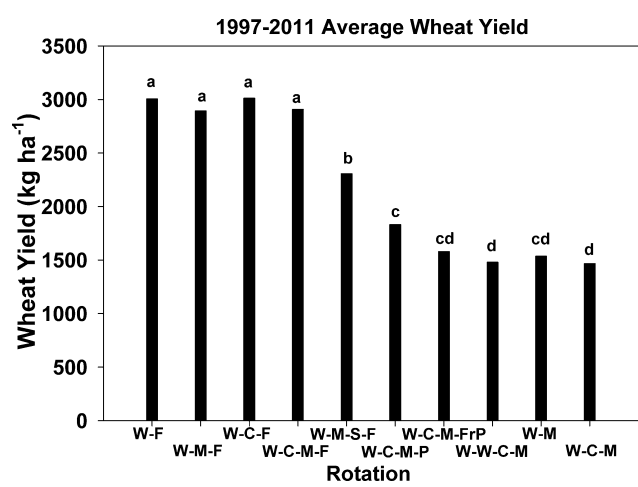

Fig. 3. Average (1997-2011) winter wheat yields for 10 dryland cropping systems at Akron, CO. Bars with the same letter above the bar are not significantly different as tested by Tukey's $\mathrm{HSD}_{0.05}(\mathrm{~W}=$ winter wheat; $\mathrm{C}=$ corn; $\mathrm{M}=$ proso millet; $\mathrm{P}=$ field pea; $\mathrm{FrP}=$ forage pea; $\mathrm{S}=$ sunflower or safflower; $\mathrm{F}=$ fallow). 
Table 1

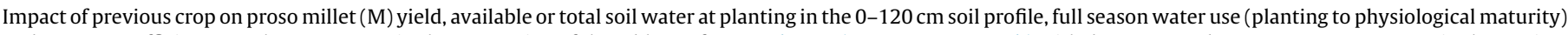

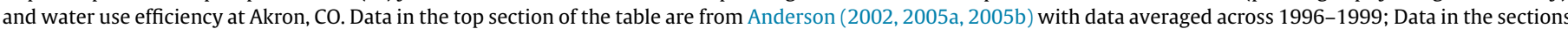

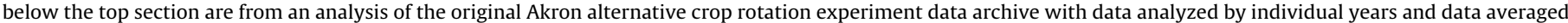
across various time periods. $\mathrm{W}=$ winter wheat, $\mathrm{C}=$ corn, $\mathrm{M}=$ proso millet.

\begin{tabular}{|c|c|c|c|c|}
\hline Data source & Agronomic data & Year & W-M & W-C-M \\
\hline \multirow[t]{4}{*}{ Anderson $(2002,2005 a, 2005 b)$} & Grain yield (kg ha $\left.{ }^{-1}\right)$ & 1996-1999 & 2020 & $2320^{*}$ \\
\hline & Available soil water at planting $(\mathrm{mm})$ & 1996-1999 & 140 & 130 \\
\hline & Water use $(\mathrm{mm})$ & 1996-1999 & 270 & 250 \\
\hline & Water use efficiency $\left(\mathrm{kg} \mathrm{ha}^{-1} \mathrm{~mm}^{-1}\right)$ & 1996-1999 & 7.5 & $9.3^{*}$ \\
\hline \multirow{16}{*}{$\begin{array}{l}\text { Akron alternative crop rotation } \\
\text { data archive (individual year data) }\end{array}$} & Grain yield (kg ha-1) & 1996 & 2670 & 3140 \\
\hline & & 1997 & 1620 & 1350 \\
\hline & & 1998 & 2100 & 2050 \\
\hline & & 1999 & 2260 & $3110^{*}$ \\
\hline & Available soil water at planting (mm) & 1996 & 324 & 328 \\
\hline & & 1997 & 224 & 189 \\
\hline & & 1998 & 228 & 235 \\
\hline & & 1999 & 255 & 272 \\
\hline & Water use (mm) & 1996 & 357 & 408 \\
\hline & & 1997 & 175 & 169 \\
\hline & & 1998 & 237 & 229 \\
\hline & & 1999 & 302 & 279 \\
\hline & Water use efficiency $\left(\mathrm{kg} \mathrm{ha}^{-1} \mathrm{~mm}^{-1}\right)$ & 1996 & 7.49 & 7.83 \\
\hline & & 1997 & 9.24 & 7.97 \\
\hline & & 1998 & 8.79 & 8.87 \\
\hline & & 1999 & 7.49 & $11.22^{*}$ \\
\hline \multirow{24}{*}{$\begin{array}{l}\text { Akron alternative crop rotation } \\
\text { data archive (averages by various } \\
\text { time periods) }\end{array}$} & Grain yield (kg ha-1) & 1996-1999 & 2160 & 2415 \\
\hline & Available soil water at planting $(\mathrm{mm}, 0-120 \mathrm{~cm})$ & 1996-1999 & 258 & 256 \\
\hline & Water use (mm) & 1996-1999 & 268 & 271 \\
\hline & Water use efficiency $\left(\mathrm{kg} \mathrm{ha}^{-1} \mathrm{~mm}^{-1}\right)$ & 1996-1999 & 8.25 & 8.97 \\
\hline & Grain yield (kg ha-1) & 1996-2011 & 2080 & $1725^{* *}$ \\
\hline & Available soil water at planting $(\mathrm{mm}, 0-120 \mathrm{~cm})$ & 1996-2011 & 287 & $261^{* *}$ \\
\hline & Water use $(\mathrm{mm})$ & 1996-2011 & 264 & $234^{* *}$ \\
\hline & Water use efficiency $\left(\mathrm{kg} \mathrm{ha}^{-1} \mathrm{~mm}^{-1}\right)$ & $1996-2011$ & 7.65 & $6.74^{*}$ \\
\hline & Grain yield (kg ha-1) & 2000-2005 & 1500 & $1055^{* *}$ \\
\hline & Available soil water at planting $(\mathrm{mm}, 0-120 \mathrm{~cm})$ & $2000-2005$ & 295 & $270^{* *}$ \\
\hline & Water use $(\mathrm{mm})$ & $2000-2005$ & 249 & $220^{* *}$ \\
\hline & Water use efficiency $\left(\mathrm{kg} \mathrm{ha}^{-1} \mathrm{~mm}^{-1}\right)$ & $2000-2005$ & 5.40 & $3.94^{* *}$ \\
\hline & Grain yield (kg ha-1) & 2006-2011 & 2605 & $1940^{*}$ \\
\hline & Available soil water at planting $(\mathrm{mm}, 0-120 \mathrm{~cm})$ & $2006-2011$ & 298 & $255^{* *}$ \\
\hline & Water use (mm) & 2006-2011 & 276 & $222^{* *}$ \\
\hline & Water use efficiency $\left(\mathrm{kg} \mathrm{ha}^{-1} \mathrm{~mm}^{-1}\right)$ & 2006-2011 & 9.50 & 8.04 \\
\hline & Grain yield (kg ha $\left.\mathrm{k}^{-1}\right)$ & Low-yielding years ${ }^{\dagger}$ & 1340 & 1095 \\
\hline & Available soil water at planting $(\mathrm{mm}, 0-120 \mathrm{~cm})$ & Low-yielding years & 255 & $233^{* *}$ \\
\hline & Water use (mm) & Low-yielding years & 233 & $203^{* *}$ \\
\hline & Water use efficiency $\left(\mathrm{kg} \mathrm{ha}^{-1} \mathrm{~mm}^{-1}\right)$ & Low-yielding years & 5.55 & 4.53 \\
\hline & Grain yield (kg ha $\left.{ }^{-1}\right)$ & High-yielding years & 2818 & $2359^{*}$ \\
\hline & Available soil water at planting $(\mathrm{mm}, 0-120 \mathrm{~cm})$ & High-yielding years & 319 & $288^{* *}$ \\
\hline & Water use $(\mathrm{mm})$ & High-yielding years & 295 & $265^{*}$ \\
\hline & Water use efficiency $\left(\mathrm{kg} \mathrm{ha}^{-1} \mathrm{~mm}^{-1}\right)$ & High-yielding years & 9.75 & 8.94 \\
\hline
\end{tabular}

*,** indicate statistically significant differences at $P=0.05,0.01$, respectively.

$\dagger$ The division between low-yielding and high-yielding years was arbitrarily set at $2300 \mathrm{~kg} \mathrm{ha}^{-1}$ millet yield in the W-M rotation. Low-yielding years were 1997,1998 , 1999, 2000, 2002, 2005, 2006, 2011. High-yielding years were 1996, 2001, 2003, 2004, 2007, 2008, $2009,2010$.

(individual year data)". In each of those four years analyzed separately there were no statistically significant differences due to rotation for grain yield, total soil water at planting in the 0 to $120 \mathrm{~cm}$ soil profiles, water use, and WUE with the exception of grain yield and WUE in 1999 when values were greater in W-C-M than in $\mathrm{W}-\mathrm{M}$. Neither was there a significant difference in any of those four quantities when averaged over the four years, although numerically greater yield, water use, and WUE were seen for millet in the $\mathrm{W}-\mathrm{C}-\mathrm{M}$ rotation (see Table 1, section labeled "Akron Alternative Crop Rotation Data Archive (averages by various time periods)"). The sources for the differences between the 4-year averages reported in Anderson (2005a) (shown in the top section of Table 1) and the 4-year averages shown in the third section of Table 1 have not been identified (R.L. Anderson, personal communication, 2012).
Although individual year data for 2000 to 2011 are not given in Table 1 , the third section of the table shows all of the data (1996-2011) averaged over different time periods. Data averaged over the entire record indicate significant differences in all four quantities due to crop rotation, but the differences are in the opposite direction from what was reported in Anderson (2005a), i.e., with corn in the rotation (W-C-M), grain yield, total soil water at planting, water use, and WUE were lower than when corn was not in the rotation (W-M). Similar results were seen when the data were averaged over 2000 to 2005, averaged over 2006 to 2011, averaged over low-yielding years, and averaged over high-yielding years (the division between low- and high-yielding years was arbitrarily set at $2300 \mathrm{~kg} \mathrm{ha}^{-1}$ in the $\mathrm{W}-\mathrm{M}$ rotation to divide the data set in half). The primary influence on millet yield appears to be water use. Water use was lower when available soil water at 
Table 2

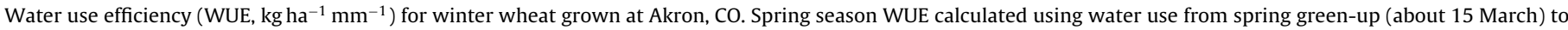

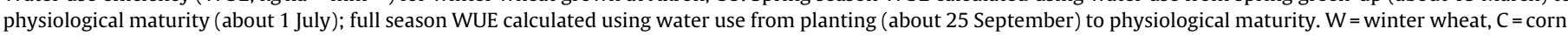
$\mathrm{M}=$ proso millet, $\mathrm{P}=$ pea, $\mathrm{S}=$ sunflower or safflower, $\mathrm{F}=$ fallow.

\begin{tabular}{|c|c|c|c|c|c|}
\hline Data source & Previous crop & Rotation & Year & Spring season $\mathrm{WUE}^{\dagger}$ & Full season $\mathrm{WUE}^{\dagger}$ \\
\hline \multirow[t]{4}{*}{ Anderson (2010) } & Pea & W-C-M-P & 1998-1999 & $9.13 \mathrm{a}$ & $\mathrm{N} / \mathrm{A}$ \\
\hline & Fallow & W-C-M-F & 1998-1999 & $8.11 \mathrm{~b}$ & $\mathrm{~N} / \mathrm{A}$ \\
\hline & Wheat & W-C-M-W & 1998-1999 & $7.26 \mathrm{c}$ & $\mathrm{N} / \mathrm{A}$ \\
\hline & Millet & W-C-M-W & 1998-1999 & $5.91 \mathrm{~d}$ & N/A \\
\hline \multirow[t]{6}{*}{ Anderson (2011) } & Fallow & W-F & 1996-1999 & $9.04 \mathrm{c}$ & $\mathrm{N} / \mathrm{A}$ \\
\hline & Fallow & W-M-F & 1996-1999 & $9.16 \mathrm{c}$ & $\mathrm{N} / \mathrm{A}$ \\
\hline & Fallow & $\mathrm{W}-\mathrm{C}-\mathrm{F}$ & 1996-1999 & $11.20 \mathrm{~b}$ & $\mathrm{~N} / \mathrm{A}$ \\
\hline & Fallow & W-C-M-F & 1996-1999 & $11.06 \mathrm{~b}$ & $\mathrm{~N} / \mathrm{A}$ \\
\hline & Fallow & W-M-S-F & 1996-1999 & $8.93 c$ & $\mathrm{~N} / \mathrm{A}$ \\
\hline & Pea & W-C-M-P & 1996-1999 & $12.34 \mathrm{a}$ & $\mathrm{N} / \mathrm{A}$ \\
\hline \multirow[t]{30}{*}{ Akron alternative crop rotation data archive } & Pea & W-C-M-P & 1998-1999 & $8.81 \mathrm{a}$ & $7.78 \mathrm{a}$ \\
\hline & Fallow & W-C-M-F & 1998-1999 & $9.52 \mathrm{ab}$ & $7.06 a$ \\
\hline & Wheat & W-C-M-W & 1998-1999 & $6.52 \mathrm{bc}$ & $5.41 \mathrm{ab}$ \\
\hline & Millet & W-C-M-W & 1998-1999 & $5.27 \mathrm{c}$ & $4.41 \mathrm{~b}$ \\
\hline & Fallow & W-F & 1996-1999 & $9.32 \mathrm{ab}$ & $7.55 \mathrm{ab}$ \\
\hline & Fallow & W-M-F & 1996-1999 & $9.70 \mathrm{ab}$ & $7.94 \mathrm{ab}$ \\
\hline & Fallow & W-C-F & 1996-1999 & $10.54 \mathrm{a}$ & $8.67 \mathrm{a}$ \\
\hline & Fallow & W-C-M-F & 1996-1999 & $10.45 \mathrm{a}$ & $8.55 \mathrm{a}$ \\
\hline & Fallow & W-M-S-F & 1996-1999 & $9.08 \mathrm{ab}$ & $7.39 \mathrm{ab}$ \\
\hline & Pea & $\mathrm{W}-\mathrm{C}-\mathrm{M}-\mathrm{P}$ & 1996-1999 & $8.36 \mathrm{~b}$ & $6.69 \mathrm{~b}$ \\
\hline & Pea & W-C-M-P & 1997-2011 & $7.44 \mathrm{~b}$ & $5.91 \mathrm{~b}$ \\
\hline & Fallow & W-C-M-F & 1997-2011 & $10.20 \mathrm{a}$ & $7.53 \mathrm{a}$ \\
\hline & Wheat & W-C-M-W & 1997-2011 & $7.74 \mathrm{~b}$ & $5.58 \mathrm{~b}$ \\
\hline & Millet & $\mathrm{W}-\mathrm{C}-\mathrm{M}-\mathrm{W}$ & $1997-2011$ & $6.30 \mathrm{~b}$ & $5.21 \mathrm{~b}$ \\
\hline & Pea & W-C-M-P & 2000-2005 & $6.93 \mathrm{ab}$ & $5.68 \mathrm{ab}$ \\
\hline & Fallow & W-C-M-F & 2000-2005 & $8.29 \mathrm{a}$ & $6.93 \mathrm{a}$ \\
\hline & Wheat & W-C-M-W & 2000-2005 & $7.13 \mathrm{ab}$ & $6.10 \mathrm{ab}$ \\
\hline & Millet & $\mathrm{W}-\mathrm{C}-\mathrm{M}-\mathrm{W}$ & $2000-2005$ & $5.88 \mathrm{~b}$ & $5.09 \mathrm{~b}$ \\
\hline & Pea & W-C-M-P & 2006-2011 & $7.08 \mathrm{a}$ & $5.41 \mathrm{~b}$ \\
\hline & Fallow & W-C-M-F & 2006-2011 & $11.98 \mathrm{a}$ & $7.68 \mathrm{a}$ \\
\hline & Wheat & W-C-M-W & 2006-2011 & $9.22 \mathrm{a}$ & $5.40 \mathrm{~b}$ \\
\hline & Millet & $\mathrm{W}-\mathrm{C}-\mathrm{M}-\mathrm{W}$ & $2006-2011$ & $6.56 \mathrm{a}$ & $5.24 \mathrm{~b}$ \\
\hline & Pea & W-C-M-P & Low-yielding years & $5.99 \mathrm{ab}$ & $4.13 \mathrm{~b}$ \\
\hline & Fallow & W-C-M-F & Low-yielding years & $10.55 \mathrm{a}$ & $6.62 \mathrm{a}$ \\
\hline & Wheat & W-C-M-W & Low-yielding years & $7.82 \mathrm{ab}$ & $4.27 \mathrm{~b}$ \\
\hline & Millet & W-C-M-W & Low-yielding years & $4.18 \mathrm{~b}$ & $3.07 \mathrm{~b}$ \\
\hline & Pea & W-C-M-P & High-yielding years & $8.72 \mathrm{ab}$ & $7.15 \mathrm{ab}$ \\
\hline & Fallow & W-C-M-F & High-yielding years & 9.89 a & 8.39 a \\
\hline & Wheat & W-C-M-W & High-yielding years & $7.68 \mathrm{~b}$ & $6.73 \mathrm{~b}$ \\
\hline & Millet & W-C-M-W & High-yielding years & $8.15 \mathrm{~b}$ & $7.08 \mathrm{~b}$ \\
\hline
\end{tabular}

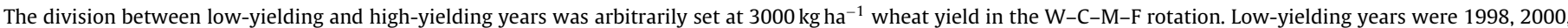
2002, 2004, 2005, 2006, 2008. High-yielding years were 1997, 1999, 2001, 2003, 2007, 2009, 2010, 2011.

† Water use efficiency values followed by the same letter within a group are not significantly different as tested by Fisher's Protected LSD (0.05) for the Anderson (2010, 2011) data sets and as tested by Tukey's HSD (0.05) for the Akron Alternative Crop Rotation data archive sets.

planting was lower, and available soil water was lower when corn was in the rotation.

\subsection{Synergistic effect of pea on winter wheat}

Anderson (2010) and Anderson (2011) stated that WUE of winter wheat was improved when wheat followed pea in a rotation compared with wheat following fallow, wheat, or millet. The WUE values taken from the figures presented in those two papers are given in the top two sections of Table 2 for reference.

Anderson (2010) showed significant differences in wheat WUE (calculated using the spring season water use from about 15 March to 1 July, 1998-1999) were related to preceding crop. The highest 2year average WUE $\left(9.13 \mathrm{~kg} \mathrm{ha}^{-1} \mathrm{~mm}^{-1}\right)$ occurred when pea was the preceding crop and the lowest average WUE $\left(5.91 \mathrm{~kg} \mathrm{ha}^{-1} \mathrm{~mm}^{-1}\right)$ occurred when proso millet was the preceding crop. Similarly Anderson (2011) showed the highest 4-year average (1996-1999) WUE (12.34 $\mathrm{kg} \mathrm{ha}^{-1} \mathrm{~mm}^{-1}$ ) occurred when pea preceded wheat.
The lower seven sections of Table 2 present the analysis of average wheat WUE using the data from the Akron ACR data archive to compare with the averages presented in Anderson (2010, 2011). The data averaged over 1998 and 1999 show spring season WUE values in the same range as reported by Anderson (2010), but somewhat different in magnitude (generally lower). Of particular note is that the mean separation statistics are not the same, and that wheat WUE for the rotation with pea as the preceding crop was numerically lower than when fallow was the preceding phase of the rotation (although the difference is not statistically significant). The analysis of the 4-year average WUE (1996-1999) indicated that wheat WUE in the rotation where wheat followed pea was significantly lower $\left(8.36 \mathrm{~kg} \mathrm{ha}^{-1} \mathrm{~mm}^{-1}\right)$ than in the $\mathrm{W}-\mathrm{C}-\mathrm{F}$ (10.54 $\mathrm{kg} \mathrm{ha}^{-1} \mathrm{~mm}^{-1}$ ) and $\mathrm{W}-\mathrm{C}-\mathrm{M}-\mathrm{F}\left(10.45 \mathrm{~kg} \mathrm{ha}^{-1} \mathrm{~mm}^{-1}\right.$ ) rotations, not higher as stated in Anderson (2011). The observed lower wheat WUE with pea as the preceding crop than when fallow was the preceding phase of the crop rotation is also seen when the analysis is done for full season WUE. Additionally, the observation of lower or equivalent WUE when wheat follows pea than 
when wheat follows fallow is seen when more years are added to the analysis (see sections of Table 2 where averaging is done over 1997-2011, 2000-2005, 2006-2011, low-yielding years, and high-yielding years). While the reduction in WUE following pea is not always statistically significant, there is never an observed statistically significant increase in WUE following pea.

While improved WUE due to crop rotation is our definition for synergism in the current analysis, it is also important to look at changes to yield due to crop rotation, as that is what farmers will be most interested in. The 15-year average wheat yield following pea or forage pea (Fig. 3) was about $1250 \mathrm{~kg} \mathrm{ha}^{-1}$ lower than wheat following fallow and similar to wheat following millet.

To correct the scientific record, it should be pointed out that both Anderson (2010) and Anderson (2011) stated that pea in the W-C-M-P rotation was grown for forage or green fallow with growth terminated after six to eight weeks of growth. However, the experimental log book entries indicate that the pea in this rotation was grown for seed and allowed to go to physiological maturity (about 12 weeks).

\section{Discussion}

We are unaware of other published data sources that might confirm or deny the existence of the synergistic effect of enhanced WUE for winter wheat with corn or pea as previous crops or enhanced WUE for proso millet with corn as the previous crop in the semiarid environment of the central Great Plains. However, Seymour et al. (2012) analyzed 167 crop sequence experiments conducted in the semi-arid region of Western Australia from 1974 to 2007. They found wheat yields were consistently greater following pea and lupin (Lupinus angustifolius L.) production, and sometimes greater following canola (Brassica napus L.) and oat (Avena sativa L.) production than found with wheat after wheat. The reasons for these yield increases were generally thought to occur because of increased $\mathrm{N}$ availability, disease suppression, or reduced weed competition. No analysis of water availability effects was possible, although they did speculate that there may have been less water used by the legumes that may have made more water available to the subsequent wheat crop. In contrast to these results that found pea to increase subsequent wheat yields, our data showed no such increase (Fig. 3). Additionally, the data presented in the lower sections of Table 2 indicate numerically greater, but not statistically significant, WUE for wheat after pea compared with wheat after wheat or wheat after millet for most of the averaging scenarios. However, the highest WUE values were always observed for wheat after fallow. These data from the ACR data archive support a previously published 6year analysis from Akron (Nielsen and Vigil, 2005) showing that water use by forage pea grown as a green fallow crop reduced wheat yields by $23 \%$ to $42 \%$, depending on pea termination date, compared with wheat yields in a W-F conventional till system. In no years of that study did growing pea ahead of wheat increase wheat yield.

Gan et al. (2003) reported six site-years of durum wheat (Triticum turgidum L.) yields as influenced by previous crops in the semi-arid region of Saskatchewan, Canada. Wheat yields were 7 to $11 \%$ greater following pulse or oilseed crops compared with wheat after spring wheat, and the yield increase was attributed in part to greater residual $\mathrm{N}$ and soil water prior to the durum wheat planting. Data from Kansas reported by Norwood (2000) showed 6-year average winter wheat yields were greatest when following corn or grain sorghum and lowest following sunflower, with the yields following soybean (Glycine max L.) intermediate. Those yields were highly correlated with available soil water content at wheat planting. From their data we calculated that the wheat yields increased at the rate of $8.3 \mathrm{~kg} \mathrm{ha}^{-1}$ per mm of available soil water. The available soil water at planting accounted for $95 \%$ of the variation in wheat yield. The wheat yields following corn were not higher than would be expected from any other preceding crop considering the amount of soil water available at planting.

The water use offset seen in the plot of yield vs. water use (e.g., Fig. 2) is sometimes interpreted as that part of the total water use attributable to evaporation. Because this amount becomes an increasingly smaller fraction of total water use as total water use increases, there can be quite different values of WUE reported for a crop depending on how much water use was used to calculate WUE. For example, using the relationship for all of the data shown in Fig. 2 would produce a WUE of $5.25 \mathrm{~kg} \mathrm{ha}^{-1} \mathrm{~mm}^{-1}$ when water use is $250 \mathrm{~mm}$ compared with $7.82 \mathrm{~kg} \mathrm{ha}^{-1} \mathrm{~mm}^{-1}$ when water use is $450 \mathrm{~mm}$. Therefore, it may be best when trying to evaluate synergistic effects of cropping systems on WUE to make those evaluations based upon whether significant differences are observed in the slopes and water use offsets of the relationships between yield and water use rather than the WUE calculated as yield divided by water use. In the current study, neither the data set presented in Fig. 2 nor the data set of average yield vs. average spring season water use (data not shown) provide evidence of greater wheat yield for a given water use when corn is a component of a crop rotation. As stated earlier, we believe full season water use rather than spring season water use should be reported as the more applicable term for evaluating differences in water use and WUE due to crop sequence as it is important to account for all of the water use by the crop. In any case, these data do not support the conclusion that winter wheat WUE (computed from any given value of either full season water use or spring season water use) is improved with corn in the rotation.

There also appears to be no indication that corn in a rotation with wheat and millet will result in greater millet yields and WUE (Table 1). Additionally, we believe that most farmers are ultimately more interested in millet yields than in millet WUE, and the results shown in Table 1 indicate that millet will generally yield 16 to $27 \%$ less with corn in the rotation than when corn is not in the rotation, depending on the averaging period chosen.

As can be seen from the data presented in Tables 1 and 2, WUE can vary widely for both wheat $\left(4.18-12.34 \mathrm{~kg} \mathrm{ha}^{-1} \mathrm{~mm}^{-1}\right.$ for spring season WUE, $3.07-8.67 \mathrm{~kg} \mathrm{ha}^{-1} \mathrm{~mm}^{-1}$ for full season WUE) and millet (4.53-11.22 $\mathrm{kg} \mathrm{ha}^{-1} \mathrm{~mm}^{-1}$ ). Some of the factors that are known to affect WUE are photosynthetic pathway (C4 vs. C3, Fisher and Turner, 1978; Tanner and Sinclair, 1983), soil fertility (Nielsen and Halvorson, 1991; Kiesselbach, 1916; Briggs and Shantz, 1913), atmospheric demand (Briggs and Shantz, 1917; Tanner and Sinclair, 1983), changes in the fraction of water use that is due to evaporation (which in dryland systems can depend on frequency of precipitation events and canopy cover; Tanner and Sinclair, 1983; Blum, 2009; Fisher and Turner, 1978), timing of water stress, e.g., greater reduction in WUE when stress occurs during reproductive development than during vegetative development (Tanner and Sinclair, 1983; Nielsen and Nelson, 1998), and severity of water stress (Blum, 2009).

These factors can potentially interact in complex ways to affect the WUE obtained in a given year. If the water content at planting is high in the surface soil layer there may be potential for increased evaporative losses of soil water early in the season when plants are small, leading to lower WUE. Situations with greater amounts of stored soil water deeper in the soil profile could lead to greater WUE as more water is available for transpiration. A pattern of frequent precipitation events could also lead to a higher fraction of water use coming from evaporation resulting in lower WUE. Differences in starting soil water due to previous crop in a rotation could also lead to differences in growing season water stress or timing of water stress that could lead to differences in WUE between rotations. Differences in WUE due to nitrogen fertility differences in different rotations should not have been a factor in the current 
experiment as the rotations were fertilized to avoid any nitrogen deficiencies.

A possible scenario in which corn ahead of wheat or millet in a rotation could result in greater WUE for those two crops than when corn is not in the rotational sequence might be one in which a large amount of corn residue is left following corn harvest. If this large amount of residue is present during a winter in which large amounts of snow are accompanied by wind (Nielsen, 1998), the starting water contents at wheat and millet planting would be high. If the growing seasons for those two crops have infrequent large precipitation events and the remaining corn residue acts as an effective mulch suppressing evaporation, and if precipitation events occur during reproductive stages, it is likely that WUE values observed for these two crops will be high.

We attempted a best subset regression analysis of several environmental factors (sum of May and June precipitation, precipitation per event in May and June, amount of snow during 12-month fallow period prior to wheat planting, and available soil water content at wheat planting) that might be important influences on full season WUE of wheat (data not shown). The analysis with data from 1996-1999 showed that WUE was most influenced by the sum of May and June precipitation and precipitation per event in May and June. Increasing May and June precipitation decreased WUE while increasing precipitation per event increased WUE. These two parameters explained $78 \%$ of the variation in WUE. Beginning soil water was not an influential parameter, and neither was total snow during the fallow period between corn/millet harvest and wheat planting.

Increasing May and June precipitation could be reasoned to have both increasing and decreasing effects on wheat WUE. It could increase WUE because this is precipitation during the reproductive and grain-filling period so that precipitation should more effectively increase yield than precipitation during other portions of the growing season. However, this precipitation would also be keeping the soil wet and increasing soil surface evaporation. As precipitation per event increases, WUE would increase as well because there is potentially more infiltration and less water loss to evaporation.

Unfortunately, when the best subset regression analysis was expanded to include all years of data reported in this study (1996-2011), none of the four parameters or any combination of parameters used in the regression analysis was significantly correlated with WUE. Perhaps there are too many interacting parameters that change from year to year to identify a consistent set of influential parameters.

\section{Conclusions}

Based on the results of this expanded study, we conclude that there is no evidence in the relationships in the data sets recorded at Akron, $\mathrm{CO}$ to support the conclusion that growing corn ahead of wheat or proso millet will consistently improve WUE of those two crops. Additionally, field pea grown ahead of wheat does not improve wheat WUE compared with WUE of wheat preceded by wheat, proso millet, or fallow. Perhaps, more importantly from a farmer's perspective is the finding that long-term average dryland wheat yield is not improved with corn in a rotation, and growing pea, whether for seed or forage, ahead of wheat will significantly decrease wheat yield to the same degree that growing millet ahead of wheat will reduce yield (Fig. 3 ). Also, corn in a rotation with millet will generally reduce millet yield.

Our analysis of 16 years of data from this long-term study conducted at Akron, CO did not detect synergism among crops, and emphasizes the importance of long-term studies of rotational cropping systems. Because of the complex interactions between variable growing season conditions, particularly timing of temperature and water stresses and water availability due to preceding crop water use in crop rotations, faulty or inaccurate conclusions can be drawn from data acquired over only a few years (Lyon et al., 2003).

\section{References}

Anderson, R.L., 2002. Designing rotations to favor natural benefits. In: Proc of NoTill on the Plains Conference, Salina, KS. 25-26 Jan. 2002. No-Till on the Plains Assoc.,Wamego, KS, pp. 7-14.

Anderson, R.L., 2004. Benefits of crop sequencing. In: Proceeding of No-Till on the Plains Conference, Salina, KS. 27-28 Jan. 2004. No-Till on the Plains Assoc.,Wamego, KS, pp. 9-17.

Anderson, R.L., 2005a. Are some crops synergistic to following crops? Agron. J. 97, 7-10.

Anderson, R.L., 2005b. Improving sustainability of cropping systems in the central Great Plains. J. Sustain. Agric. 26, 97-114.

Anderson, R.L., 2010. Rotation design: a critical factor for sustainable crop production in a semiarid climate: a review. In: Organic Farming, Pest Control and Remediation of Soil Pollutants, Sustainable Agriculture Reviews 1. Springer Publishing, Secaucus, NJ, pp. 107-121.

Anderson, R.L., 2011. Synergism: a rotation effect of improved growth efficiency. In: Sparks, D.L. (Ed.), Advances in Agronomy, 112. Academic Press, New York, pp. 205-226.

Anderson, R.L., Bowman, R.A., Nielsen, D.C., Vigil, M.F., Aiken, R.M., Benjamin, J.G., 1999. Alternative crop rotations for the central Great Plains. J. Prod. Agric. 12, 95-99.

Benjamin, J.G., Halvorson, A.D., Nielsen, D.C., Mikha, M.M., 2010. Crop management effects on crop residue production and changes in soil organic carbon in the central Great Plains. Agron. J. 102, 990-997.

Blum, A., 2009. Effective use of water (EUW) and not water-use efficiency (WUE) is the target of crop yield improvement under drought stress. Field Crops Res. 112, 119-123.

Briggs, L.J., Shantz, H.L., 1913. The Water Requirement of Plants: II. A Review of the Literature. USDA Bureau Plant Industry Bull, pp. 285

Briggs, L.J., Shantz, H.L., 1917. The water requirement of plants as influenced by environment. In: Proceeding of 2nd Pan American Science Congress. Washington, D.C., pp. 95-107, 3.

Farahani, H.J., Peterson, G.A., Westfall, D.G., 1998. Dryland cropping intensification: a fundamental solution to efficient use of precipitation. Adv. Agron. 64, 225-265.

Felter, D.G., Lyon, D.J., Nielsen, D.C., 2006. Evaluating crops for a flexible summer cropping system. Agron. J. 98, 1510-1517.

Fisher, R.A., Turner, N.C., 1978. Plant productivity in the arid and semiarid zones. Ann. Rev. Plant Physiol. 29, 277-317.

Gan, Y.T., Miller, P.R., McConkey, B.G., Zentner, R.P., Stevenson, F.C., McDonald, C.L., 2003. Influence of diverse cropping sequences on durum wheat yield and protein in the semiarid northern Great Plains. Agron. J. 95, 245-252.

Hatfield, J.L., Sauer, T.J., Prueger, J.H., 2001. Managing soils to achieve greater water use efficiency. A review. Agron. J. 93, 271-280.

Keating, B.A., Carberry, P.S., Hammer, G.L., 2003. An overview of APSIM a model designed for farming systems simulation. Eur. J. Agron. 18, 267-288.

Kiesselbach, T.A., 1916. Transpiration as a Factor in Crop Production. Nebraska Agric Exp. Stn. Bull., Lincoln, NE (USA) 6

Kirkegaard, J., Christen, O., Krupinsky, J., Layzell, D., 2008. Break crop benefits in temperate wheat production. Field Crop. Res. 107, 185-195.

Kirkegaard, J.A., Hunt, J.R., 2010. Increasing productivity by matching farming system management and genotype in water-limited environments. J. Exp. Bot. 61, 4129-4143.

Lenssen, A.W., Johnson, G.D., Carlson, G.R., 2007. Cropping sequence and tillage system influences annual crop production and water use in semiarid Montana, USA. Field Crop. Res. 100, 32-43.

Lyon, D.J., Hammer, G.L., McLean, G.B., Blumenthal, J.M., 2003. Simulation supplements field studies to determine no-till dryland corn population recommendations for semiarid western Nebraska. Agron. J. 95, 884-891.

Lyon, D.J., Nielsen, D.C., Felter, D.G., Burgener, P.A., 2007. Choice of summer fallow replacement crops impacts subsequent winter wheat. Agron. J. 99, 578-584.

Miller, P.R., Gan, Y., McConkey, B.G., McDonald, C.L., 2003. Pulse crops for the northern Great Plains: II. Cropping sequence effects on cereal, oilseed, and pulse crops. Agron. J. 95, 980-986.

Nielsen, D.C., 1998. Snow catch and soil water recharge in standing sunflower residue. J. Prod. Agric. 11, 476-480.

Nielsen, D.C., Anderson, R.L., Bowman, R.A., Aiken, R.M., Vigil, M.F., Benjamin, J.G. 1999. Winter wheat and proso millet yield reduction due to sunflower in rotation. J. Prod. Agric. 12, 193-197.

Nielsen, D.C., Halvorson, A.D., 1991. Nitrogen fertility influence on water stress and yield of winter wheat. Agron. J. 83, 1065-1070.

Nielsen, D.C., Nelson, N.O., 1998. Black bean sensitivity to water stress at various growth stages. Crop Sci. 38, 422-427. 
Nielsen, D.C., Vigil, M.F., 2005. Legume green fallow effect on soil water content at wheat planting and wheat yield. Agron. J. 97, 684-689.

Nielsen, D.C., Vigil, M.F., 2010. Precipitation storage efficiency during fallow in wheat-fallow systems. Agron. J. 102, 537-543.

Nielsen, D.C., Vigil, M.F., Anderson, R.L., Bowman, R.A., Benjamin, J.G., Halvorson, A.D., 2002. Cropping system influence on planting water content and yield of winter wheat. Agron. J. 94, 962-967.

Nielsen, D.C., Vigil, M.F., Benjamin, J.G., 2008. The variable response of dryland corn yield to soil water content at planting. Agr. Water Manage. 96, 330-336.

Norwood, C.A., 2000. Dryland winter wheat as affected by previous crop. Agron. J. $92,121-127$.
Saseendran, S.A., Nielsen, D.C., Ma, L., Ahuja, L.R., Vigil, M.F., 2010. Simulating alternative dryland rotational cropping systems in the central Great Plains with RZWQM2. Agron. J. 102, 1521-1534.

Seymour, M., Kirkegaard, J.A., Peoples, M.B., White, P.F., French, R.J., 2012. Breakcrop benefits to wheat in Western Australia-insights from over three decades of research. Crop Pasture Sci. 63, 1-16.

Tanaka, D.L., Anderson, R.L., Rao, S.C., 2005. Crop sequencing to improve use of precipitation and synergize crop growth. Agron. J. 97, 385-390.

Tanner, C.B., Sinclair, T.R., 1983. Efficient water use in crop production: research or re-search? In: Taylor, H.M., Jordan, W.R., Sinclair, T.R. (Eds.), Limitations to Efficient Water Use. American Society of Agronomy, Madison, WI (USA), pp. 1-27. 